Article

\title{
Digital Competencies for New Journalistic Work in Media Outlets: A Systematic Review
}

\author{
Salvador Reyes-de-Cózar *, Marta Pérez-Escolar, and Pablo Navazo-Ostúa \\ Department of Communication and Education, Universidad Loyola Andalucía, Spain \\ * Corresponding author (sreyes@uloyola.es)
}

Submitted: 29 April 2021 | Accepted: 25 November 2021 | Published: 20 January 2022

\begin{abstract}
Media organizations operate in a rivalry-charged ecosystem nowadays, as a consequence of emerging patterns of news production, distribution, and consumption. Furthermore, the growing of public social media manifestations and the arrival of digital journalism require new professional roles, responsibilities, and skills inside the media industry. In this context, Faculties of Communication need to equip students with the digital competencies that are relevant to new media outlets and journalistic work. Based on this approach, the main objective of this study is to answer the following questions: What does the literature suggest about the digital skills that new professional profiles should acquire in the field of journalism? Which dimensions of digital competence are gaining visibility and which dimensions are being neglected? To answer the scientific objectives, a systematic review has been carried out following the PRISMA (Preferred Reporting Items for Systematic Reviews and Meta-Analyses) statement. The application of the two models of digital competence, Bloom's taxonomy (1956), and digital competence in education (Redecker, 2017), serves as a framework in two ways: to determine the level of digital competence development, and to identify the dimensions on which greater emphasis is being placed. The results show a lack of studies linked to key aspects of digital competence, especially those related to personal growth, emotional state (Redecker, 2017), and the development of a deep level of acquisition of this competence (Bloom, 1956). This article proposes to reflect on whether we want to train professionals according to the model demanded by the media outlets nowadays, or whether we prefer to train communication professionals with a deep level of digital competence, since they are able to respond to the future and changing needs of the 21 st century.
\end{abstract}

\section{Keywords}

digital competence; digital journalism; digital skills; journalism; new media outlet; professional profiles

\section{Issue}

This article is part of the issue "New Forms of Media Work and its Organizational and Institutional Conditions: Issue Information" edited by Salla-Maaria Laaksonen (University of Helsinki) and Mikko Villi (University of Jyväskylä).

(C) 2022 by the author(s); licensee Cogitatio (Lisbon, Portugal). This article is licensed under a Creative Commons Attribution 4.0 International License (CC BY).

\section{Introduction}

In 2020, an artificial intelligent new language generator, GPT-3, wrote an essay, entitled "Are You Scared Yet, Human?," in The Guardian, to convince citizens that robots come in peace (GPT-3, 2020). This article expressed deep concern about the future of journalism and challenged the new competencies and skills of students at the faculties of communication. Thus, it has become increasingly obvious and plain that journalists and media organisations operate in a "hypercompetitive environment" (Chadwick, 2011, p. 3) and face different dilemmas currently. The emerging patterns of news production, distribution, and consumption (Carlson, 2017; Jensen et al., 2016; Salaverría \& De-Lima-Santos, 2020), the growing public social media manifestations, and the arrival of digital journalism-described as a "highly elusive, changing, multifaceted concept" (Salaverría, 2019, p. 2)-among other phenomena, also emphasise the need to tackle this rivalry-ridden ecosystem. This can be 
achieved by training new professionals in skills, responsibilities, and roles in line with the requirements of the new labour market and the media industry.

For some authors (Berganza et al., 2017; Cruz-Álvarez \& Suarez-Villegas, 2017; García-Orosa et al., 2020; Lugo-Ortiz, 2016; Sánchez-García, 2016), the future of journalism relies on keeping its essence instead of training students in new technologies. Accordingly, Lazo et al. (2020) stress that there are traditional competencies in journalism that graduates should always acquire, regardless of whether professionals operate in online or offline environments since the absence of these skills would lead to an "identity crisis of journalism, with deep and disastrous consequences for the profession, the society and democracy" (p. 55). In this sense, Lazo et al. (2020) propose that the most noteworthy classical competencies and skills of journalists are "professional identity competencies, solidarity competencies, narrative skills, reporting skills, ethical, deontological and juridical competencies, psychosocial skills, social commitment competencies, creativity, speculative competencies and autonomous learning skills" (p. 55).

Other scholars (Bruns, 2016; Diakopoulos, 2015; Goggin, 2020; Heravi et al., 2021; Lewis \& Westlund, 2016; Steensen \& Westlund, 2021) argue that in this new digital landscape, the journalism process itself has changed radically. Therefore, the emergence of new journalistic works has pushed professionals to quickly incorporate new digital skills and competencies in this changing media landscape. In this line, many new insights for new professionals range from data journalism (Appelgren \& Lindén, 2020) to online participatory journalism (Abbott, 2017; Engelke, 2019), mobile journalism (Burum \& Quinn, 2016), and fact-checking journalism. For example, according to Graves (2016), journalists will comprise fact-checking agents and many non-professionals who will combat disinformation to recover the prestige and credibility of journalism and the media industry, mainly after the spate of false narratives surrounding Covid-19 (Luengo \& García-Marín, 2020), among other growing fields.

This new media ecosystem also entails other complex changes that jeopardise the future of the journalistic profession, since the internet and social media offer average people the ability to instantly transmit information globally (Chung, 2008; Currie, 2012; Rogers, 2016). As Shirky (2008) states, "if anyone can be a publisher, then anyone can be a journalist" (p. 71). Analysing citizen journalism and the open comments section on social media and internet forums clearly shows that participants communicate and interact with one another and the media channel, creating online discussions that may even gain more attention than the news articles posted by the hosting website itself (López-Vidales \& González-Aldea, 2014). For this reason, social media editors also work to smooth out the rougher areas of social media journalism, so they can incorporate new technology responsibly and try to stem the flow of inaccurate information (Myers, 2011).
Contrary to this line of thought, Simon (mediagrrl9, 2009) is critical of certain aspects of citizen journalism, since the structure of professional news organisations provides that ability for reputable journalists to use the sum of their time and professional experience to gather information, cross-check facts, and publish the news (Paine, 2015). Individuals doing anything else are amateurs pursuing the task without compensation, training, or, for that matter, sufficient standing (mediagrrl9, 2009). Nonetheless, the internet and social media are assets for the spread of media activism (Pickard \& Yang, 2017), specifically, in the context where the media are controlled and there is government censorship, a state that has stonewalled a great deal of newspaper reporting, but independent bloggers have still been able to uncover corruption and spur political action (Hassid, 2012; Paine, 2015).

Similarly, there is indeed a broad diversity of professional profiles in today's digital media newsrooms: writers or editors, data journalists, visual journalists (Cairo, 2015; Zavoina \& Reichert, 2000), transmedia journalists (Renó \& Flores, 2012), social media journalists and content curators (Renó \& Renó, 2015), mobile journalists, and so on.

In this context, studying the competencies and skills for new journalistic work in media organisations has become an increasingly indispensable and urgent issue for professionals and scholars. In this research, we focus on digital skills and competencies for two fundamental reasons. First, examining general skills and competencies in journalism implies taking sides in an academic discussion that has been widely researched and debated, as demonstrated above. Second, the figure of the journalist had continuously evolved over the 20th century, although these transformations have occurred more acutely over the first two decades of the 21st century, mainly because the journalistic profession has continually changed to keep pace with technology. Therefore, to fully understand the new skills and competencies that these new professionals should acquire, it is essential to frame the research in the digital realm since it is currently the most common environment where journalists operate. This concrete framework also allows us to avoid outlining the future of journalism as vague and undefined.

However, in order to carry out a systematic review of the digital competencies that are necessary to develop the profession of journalist in the coming years, we first need to establish a theoretical framework that will serve as a model for understanding or framing digital competence. In this sense, the authors of this study have decided to use Bloom's taxonomy (1956) as a regulatory and measurement framework of digital competence, since Bloom's taxonomy (1956) is a reference model in the field of technologies and has a long trajectory in the scientific literature (Figure 1). Moreover, its specialization by categories and levels of acquisition is considered especially appealing to catalogue the findings of the systematic review in the following levels, which allows us 


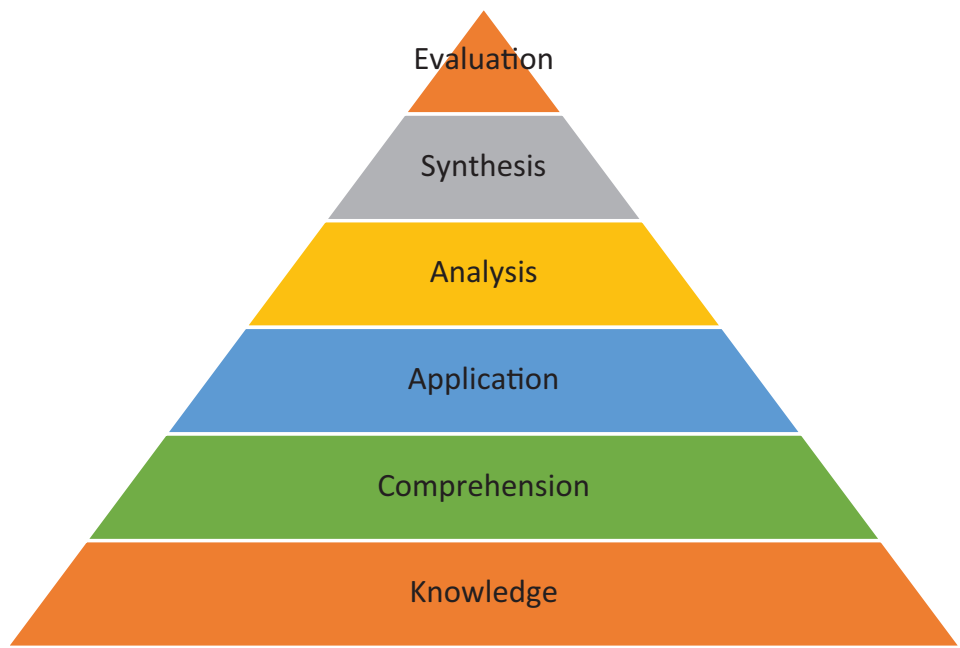

Figure 1. Bloom's taxonomy. Source: Adapted from Bloom (1956).

to map a possible training itinerary in the new journalism degrees.

The main objective of this study is to present a theoretical basis that can offer an overview of what is required in the journalism profession, as well as to provide some lines of action that could be incorporated in the curricular designs of the new degrees. Regarding this purpose, it is considered that the model of digital competence in education (DigCompEdu; Redecker, 2017) stands out as the necessary regulatory framework in which to check which aspects are being implemented in the training plans and which are necessary to include, review, or rethink (Figure 2).

Thus, we attempt to answer this question at the core of our research: What does the literature suggest about the digital skills that new professional profiles should acquire in the field of journalism? Which dimen- sions of digital competence are gaining visibility and which dimensions are being neglected? To shed light on these central questions, we have conducted a systematic review of the literature to understand the current state of this topic. In doing so, we have included research articles published over the last 10 years, from 2011 until our search was finished in June 2021.

\section{Methodology}

Our study advances a systematic review of the literature to understand the digital competencies and skills for the new professional profiles in the journalism field. New journalistic work in the social media era requires new professional roles, responsibilities, and skills within the media industry. Drawing on the emerging patterns of news production, distribution,

\begin{tabular}{|c|c|c|c|}
\hline \multirow{2}{*}{$\begin{array}{l}\text { 1. Professional } \\
\text { Engagement }\end{array}$} & 2. Digital Resources & \multirow{4}{*}{$\begin{array}{l}\text { 5. Empowering } \\
\text { Learners } \\
\text { Using digital tools } \\
\text { to empower } \\
\text { learners through: }\end{array}$} & \multirow{3}{*}{$\begin{array}{l}\text { 6. Facilitating } \\
\text { Learners' Digital } \\
\text { Competence }\end{array}$} \\
\hline & 2.1 Selecting & & \\
\hline \multirow{3}{*}{$\begin{array}{l}\text { 1.1 Data } \\
\text { management }\end{array}$} & 2.2 Organising \& sharing & & \\
\hline & 2.3 Creating & & \multirow{2}{*}{$\begin{array}{l}6.1 \text { Information \& } \\
\text { media literacy }\end{array}$} \\
\hline & 3. Digital Pedagogy & \multirow{4}{*}{$\begin{array}{l}5.1 \text { Accessibility \& } \\
\text { inclusion }\end{array}$} & \\
\hline \multirow{2}{*}{ 1.2 Communication } & Using digital tools to enhance \& innovate & & \multirow{3}{*}{ 6.2 Communication } \\
\hline & 3.1 Instruction & & \\
\hline \multirow{3}{*}{$\begin{array}{l}\text { 1.3 Professional } \\
\text { collaboration }\end{array}$} & 3.2 Teacher-learner interaction & & \\
\hline & 3.3 Learner collaboration & \multirow{3}{*}{$\begin{array}{l}5.2 \text { Differentiation } \\
\text { \& personalisation }\end{array}$} & \multirow{2}{*}{6.3 Content creation } \\
\hline & 3.4 Self-directed learning & & \\
\hline \multirow[t]{2}{*}{$\begin{array}{l}1.4 \text { Reflective } \\
\text { practice }\end{array}$} & $\begin{array}{l}\text { 4. Digital Assessment } \\
\text { Using digital tools to enhance \& innovate }\end{array}$ & & \multirow[t]{2}{*}{ 6.4 Wellbeing } \\
\hline & 4.1 Assessment formats & \multirow{3}{*}{$\begin{array}{l}5.3 \text { Actively } \\
\text { engaging } \\
\text { learners }\end{array}$} & \\
\hline \multirow{2}{*}{ 1.5 Digital CPD } & 4.2 Analysing evidence & & \multirow{2}{*}{ 6.5 Problem solving } \\
\hline & 4.3 Feedback \& planning & & \\
\hline
\end{tabular}

Figure 2. Overview of the digital competence in education framework. Source: Redecker (2017). 
and consumption (Carlson, 2017; Jensen et al., 2016; Salaverría \& De-Lima-Santos, 2020), as well as the growing public social media manifestations and the arrival of digital journalism as a "highly elusive, changing, multifaceted concept" (Salaverría, 2019, p. 2), we conducted this literature review to shed light on overall trends in digital competencies and to identify previous studies in this research area. Moreover, based on two framework models of digital competence, such as Bloom's taxonomy (1956) and Cruz's taxonomy (2020), and the DigCompEdu model, we will try to make an in-depth analysis of which aspects of digital competence are being bolstered in journalism degrees and which are being forgotten, leading to a lack of competence in information professionals. Along this line, we reviewed several types of literature, following the items recommended in the PRISMA (Preferred Reporting Items for Systematic Reviews and Meta-Analyses) statement (Moher et al., 2009; Urrutia \& Bonfill, 2013), to ensure the validity and the accuracy of the process. The remainder of this methodology section is organised as follows: in Section 2.1, we itemise the research question and outline the scope of this work. In Section 2.2, we highlight the features and values of systematic literature reviews and assess the appropriateness of applying this method to this study. Finally, in Section 2.3, we present and expound on our procedure in carrying out this systematic review.

\subsection{Scoping}

The formulation of research questions is one of the first steps in terms of defining the scope of a systematic review, guiding the decision making throughout the review process and ensuring more focused findings (Counsell, 1997; Petticrew \& Roberts, 2006; Siddaway et al., 2019). Given this, we attempt to answer this core question: What does the literature suggest about the digital skills that new professional profiles should acquire in the field of journalism? Which dimensions of digital competence are gaining visibility and which dimensions are being neglected?

\subsection{Systematic Literature Review}

Whereas reviewing the literature "involves selectively discussing the literature on a particular topic to make the argument that a new study will make a new and/or important contribution to knowledge" (Siddaway et al., 2019, pp. 750-751). The literature review is a research method that addresses much broader questions, leading researchers to draw firm conclusions based on existing conceptualisations (Siddaway et al., 2019). For this reason, a systematic review is a useful qualitative and structured method of identifying previous studies in each research area (Siddaway et al., 2019). The literature review contributes to categorizing the studies to answer specific research questions (Grant \& Booth, 2009; Williams, 2019), as well as revealing trends, connections across many studies and any gaps that need to be filled (Petticrew, 2001; Petticrew \& Roberts, 2006). In doing so, this systematic review provides a database comprising all the literature relevant to digital competencies and skills for new journalistic work in media organisations.

\subsection{Literature Search Process}

Our approach consisted of two parts. Initially, we conducted a search process that started in January 2021, using the terms "digital journalism" and "digital skills" in the Web of Science (WoS) and Scopus. However, the obtained results were too broad and relatively uninteresting, giving the main objective of this study (to determine the overall trends and common patterns in publications that investigate the digital competencies and skills for the new professional profiles in the journalism field). Therefore, after this step, we undertook another search in which we used the Boolean operators AND and OR, adding the descriptors "media industry," "social media," "journalistic work," "journalistic routines," "professional competencies," "professional responsibilities," "professional skills," and "professional roles." Although the latter search improved the specificity of the results, the generated scientific publications were either too wide and extensive or too scarce and of little value for conducting a systematic review. These two initial searches positively contributed to developing a global overview of the studied subject and to reinforcing the suitability of conducting a systematic review of the literature.

In the second phase, we carried out a new search strategy to better achieve our purpose. In view of the obtained references, finally, in September 2021, it was decided to broaden the search by trying to conduct the widest possible literature review incorporating the findings found in the Scopus, WoS, and ScienceDirect electronic databases over the last 10 years, from 2011 until our search was finished in September 2021. Using these criteria, this final search strategy was formulated as follows:

(Digital journalism skills) AND ((media industry) OR (social media) OR (journalistic work) OR (journalistic routines) OR (professional competencies) OR (professional responsibilities) OR (professional skills) OR (professional roles))

This process generated a total of 5,325 items $(4,035$ in Scopus, 1,132 in ScienceDirect, and 158 in WoS databases). Then, we applied the inclusion and exclusion criteria following the PICOS model for narrowing down the results, as Table 1 shows.

After the identification of the 5,325 generated items, we applied the inclusion and exclusion criteria (listed in Table 1), which allowed us to focus on the research question, narrow down the existing literature and delimit the systematic review (Siddaway et al., 2019). Taking into consideration these criteria, 3,531 references were 
Table 1. PICOS model.

\begin{tabular}{lll}
\hline & Inclusion criteria & Exclusion criteria \\
\hline Participant & Any participants & None \\
Intervention & Any interventions & None \\
Comparator/Context* & Social science & No publications published between 2011 \\
& Research papers & and 2021 \\
& Published publications & None in social science \\
& $\begin{array}{l}\text { Papers that deal with journalism or digital } \\
\text { journalism specifically }\end{array}$ & No research papers \\
Outcomes & Papers that deal with competencies and skills & No published papers \\
Study design & Any study designs & Others
\end{tabular}

Note: The "Context" item is marked with an asterisk $\left(^{*}\right)$ because we have replaced the "Comparator" component, which is included in the classic PICOS models, with "Context" since it better fits the methodological needs of the studies in the field of social sciences. Source: Adapted from PICOS framework (Colás-Bravo et al, 2021).

excluded for the following reasons: 1,687 were not published between 2011-2021, 909 did not belong to the social science field, 766 were not research papers, and 169 had not been published yet. Consequently, this selection phase left 1,794 unique items. Subsequently, we screened the 1,643 remaining references, examining their titles and abstracts to identify the appropriate studies that tackled the subject of our study, leaving a total of 151 publications that fully satisfied the requirements detailed in Table 1.

Finally, after examining the full texts of the 151 items, we excluded 112 papers because they did not deal with journalism or digital journalism specifically or did not refer to competencies or skills or even failed to meet any of the above criteria that we had not identified in prior phases. Then, 39 items were included in the systematic review (see the full process in Figure 3). No manual results were added from additional databases because no relevant results were found for our study.

\section{Results and Discussion}

In this section, we present the results of our systematic review of the literature. Given the objective of the study, this section consists of three distinct parts. Firstly, the general results of the systematic review are presented according to the characteristics of the studies. Secondly, the studies found in the systematic review are catalogued based on Bloom's taxonomy (1956) and Cruz's taxonomy (2020). Both proposals will allow us to tackle what competencies and competency levels professionals are demanding in the last decade. Finally, the studies are arranged based on the DigCompEdu model of digital competence in education (Redecker, 2017). Hence, it is possible to establish which dimensions of digital competence are being emphasized and which are being left aside. The DigCompEdu framework is a model of digital competence that should guide the development of present and future curricula; therefore, the study of these aspects would allow us to assess whether the current curricula are addressing all the necessary aspects of digital competence.

Regarding the main characteristics of these publications (see Table 2 and Figure 4), most of the studies that deal with digital competencies and skills in the journalism field apply a qualitative methodology ( $n=14$; $36 \%)$, such as interviews, observations, and case studies. Additionally, nine publications (23\%) are theoretical studies essentially. Eight publications (21\%) employ a mixed methodology. Eight research studies (21\%) are based on quantitative analysis, using questionnaires and descriptive and inferential methods. In general, these findings might reveal a strong upward trend in qualitative procedures, using interviews, observations, case studies or theoretical reflections.

It should be stressed that these publications also present different sorts of samples in their research. According to Pozo et al. (2012), the profiles of individuals who participate in studies are broad and heterogeneous; therefore, the criterion for their selection is a key point when carrying out an analysis. For this reason, based on the taxonomy proposed by Pozo et al. (2012), we have distributed the 39 publications comprising our sample according to the following profiles:

- Specialists; This group consists of specialists who do not belong directly to the education domain but are experts in the communication field due to their professional competency and experience.

- Involved: This group is made up of students.

- Facilitators: We include academics and university professors in this group. 


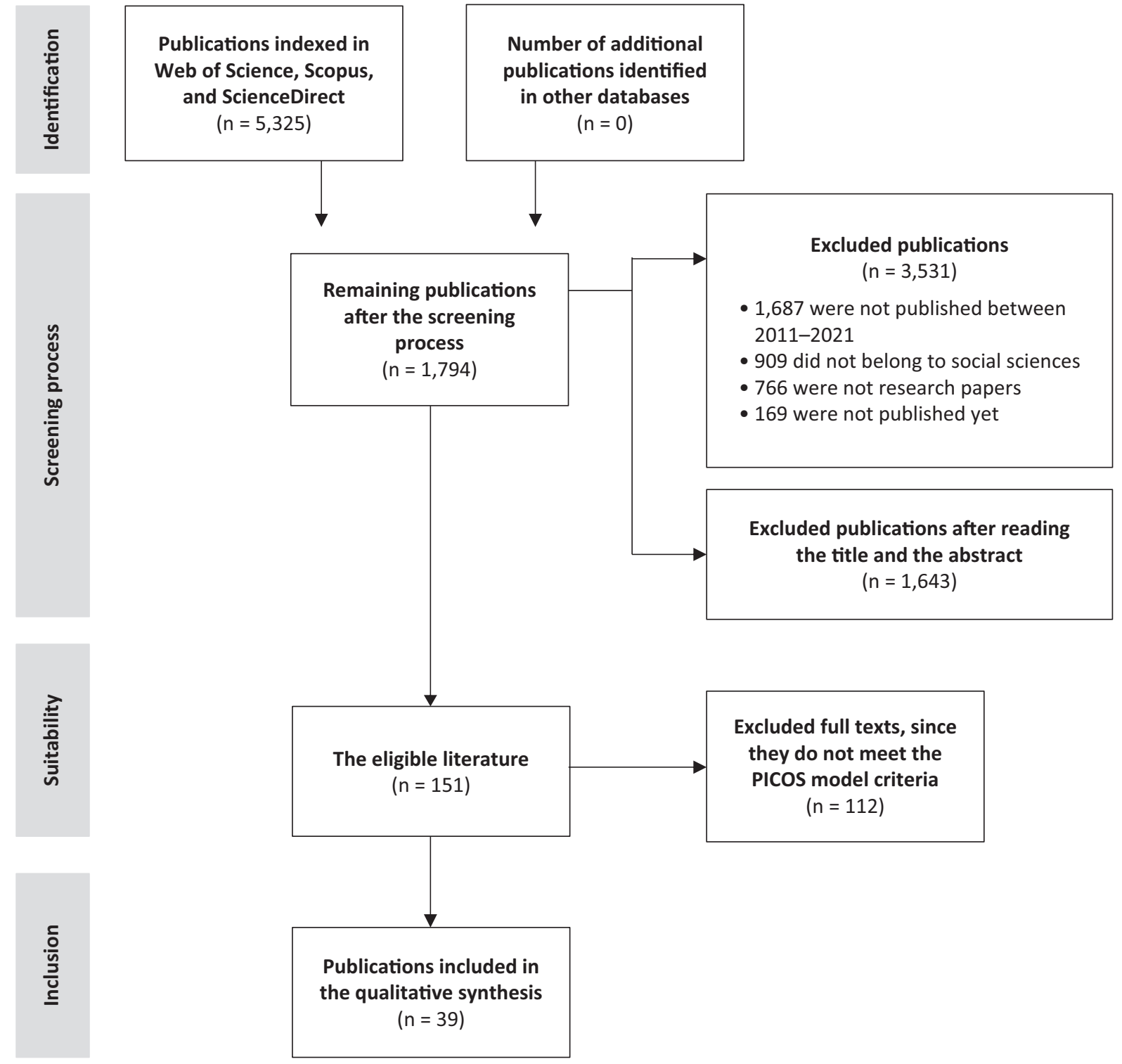

Figure 3. Planning, identification, and eligibility process workflow.

Bearing in mind that one research study could use two or more participant profiles, the "specialist" profile is the most prolific type in the sample (Table 2 and Figure 5). Fifteen publications have used journalists, founders of start-ups, media professionals, directors and supervisors of media outlets, news editors in press departments, managers of strategic communications companies, and executive producers of small audio-visual production companies. Likewise, six studies use the "involved" profile, since their samples consist of college students and

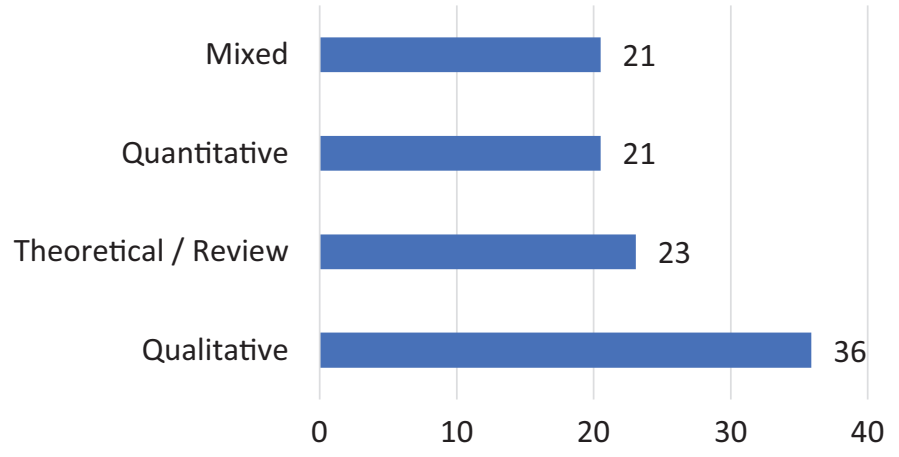

Figure 4. Percentage of studies by methodology. 


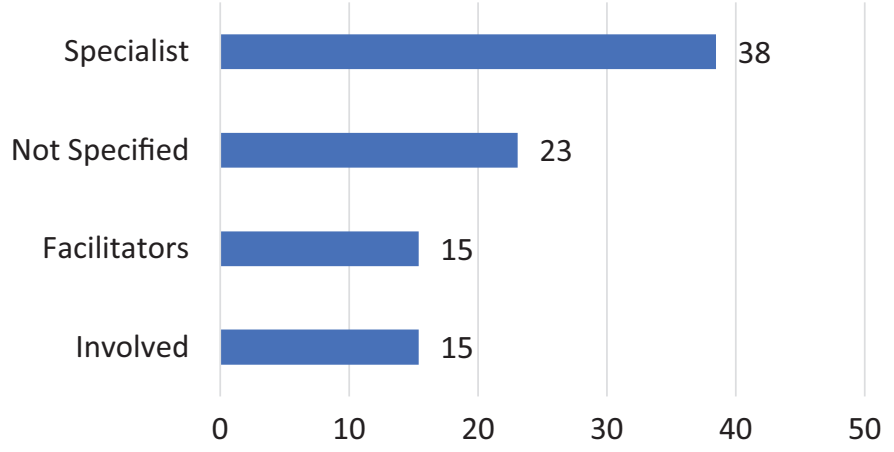

Figure 5. Percentage of studies by samples.

journalism and audio-visual communication students. Lastly, the "facilitator" profile is used in six research studies that have university professors and academics in their samples. Interestingly, there are nine publications in which the authors have not gathered any sampling, number of participants, or methods. Moreover, the sam- ples of three studies comprise different sorts of narratives, such as the syllabi or study programmes of different universities, and previous publications when conducting a literature review.

Table 2 summarises the main characteristics of the publications included in the qualitative synthesis.

Table 2. Main characteristics of the publications included in the qualitative synthesis.

\begin{tabular}{|c|c|c|c|}
\hline ID & Publication & Sample & Methodology \\
\hline P1 & Aceituno et al. (2014) & 237 college students & Quantitative: descriptive and inferential \\
\hline P2 & $\begin{array}{l}\text { Anderson and Bourke } \\
(2020)\end{array}$ & Not applicable & Theoretical \\
\hline P3 & $\begin{array}{l}\text { Appelgren and Lindén } \\
\text { (2020) }\end{array}$ & $\begin{array}{l}\text { Founders of two news start-ups in } \\
\text { Stockholm }\end{array}$ & Qualitative methodology/case studies \\
\hline P4 & Calvo and Ufarte (2020) & $\begin{array}{l}\text { Responsible for innovation of various } \\
\text { national media, university teachers, } \\
\text { journalists and journalism and audiovisual } \\
\text { communication students }\end{array}$ & $\begin{array}{l}\text { Mixed: qualitative/interview and } \\
\text { quantitative/questionnaires }\end{array}$ \\
\hline P5 & Chen (2018) & $\begin{array}{l}475 \text { scholarly journal articles in } \\
\text { librarianship and journalism }\end{array}$ & $\begin{array}{l}\text { Quantitative and qualitative comparative } \\
\text { study }\end{array}$ \\
\hline P6 & Flores (2018) & Not specified & Mixed: case study and observation \\
\hline P7 & Gulyas (2017) & 2,762 journalists & Quantitative/descriptive \\
\hline P8 & Jiang and Rafeeq (2019) & $\begin{array}{l}\text { Six students, five professionals in } \\
\text { communication, and four teachers from } \\
\text { faculties of journalism }\end{array}$ & $\begin{array}{l}\text { Qualitative/focus groups and in-depth } \\
\text { interviews }\end{array}$ \\
\hline P9 & Josephi (2019) & Not applicable & Theoretical \\
\hline P10 & Karaduman (2015) & Not specified & $\begin{array}{l}\text { Mixed: theoretical and in-depth } \\
\text { interviews }\end{array}$ \\
\hline P11 & Kõuts-Klemm (2019) & 10 journalists from different media outlets & Qualitative/in-depth interviews \\
\hline P12 & $\begin{array}{l}\text { Labio-Bernal et al. } \\
\text { (2020) }\end{array}$ & 107 teachers & Quantitative/survey \\
\hline P13 & Lazo et al. (2020) & $\begin{array}{l}119 \text { articles indexed in Web of } \\
\text { Science (54) and Scopus (65) between } \\
1998 \text { and } 2017\end{array}$ & Literature review \\
\hline
\end{tabular}


Table 2. (Cont.) Main characteristics of the publications included in the qualitative synthesis.

\begin{tabular}{llll}
\hline ID & Publication & Sample & Methodology \\
\hline P14 & $\begin{array}{l}\text { López-Vidales and } \\
\text { González-Aldea (2014) }\end{array}$ & 199 students & Qualitative/observation \\
P15 & López et al. (2019) & Not applicable & Theoretical \\
P16 & $\begin{array}{l}\text { López-Martín and } \\
\text { Córdoba-Cabús (2020) }\end{array}$ & 20 public journalism universities & Qualitative/content analysis
\end{tabular}

P17 Lugo-Ortiz (2016)

P18 Macmillan (2014)

P19 Manfredi et al. (2019)

P20 Oliveira and Angeluci (2019)

P21 Pellegrini and Grassau (2018)

P22 Recio and Santos (2014)

P23 Reilly (2018)

P24 Robinson et al. (2021)

P25 Saavedra et al. (2020)

P26 Saks et al. (2019)

P27 Schaich (2012)

P28 Sewchurran and Hofmeyr (2020)

P29 Stoker (2015)

P30 Tsymbal et al. (2020)

P31 Túñez et al. (2021)

P32 Ufarte et al. (2018)
Students, teachers, media professionals, and directors and supervisors of media outlets

215 journalism students

Not applicable

One market specialist, two national media professionals, and three researchers from Brazilian universities

News editors in press departments, managers of strategic communications companies, and executive producers of small audiovisual production companies

Not applicable

The top 10 schools in the US, ranked according to the number of journalism and mass communication graduates

Not specified

Total universe of official university bachelor's and master's degrees related to data journalism in Spain and offered in the 2019-2020 academic year

4,387 tweets

Not specified

Not applicable

Six students

Journalism students

12 experts from the main universities in Spain and heads of companies and of relevant associations in the sector

Seven university professors
Quantitative/descriptive and inferential media

Five-year qualitative study

Theoretical

Mixed: theoretical and

qualitative/semi-structured interviews

Qualitative/in-depth interviews

Theoretical study based on a teaching innovation project

Qualitative: Content analysis of journalism courses at US undergraduate and graduate schools

Mixed: in-depth interviews and textual analyses

Quantitative/descriptive and inferential

Quantitative: a constructed-sample content analysis

Qualitative/case study

Theoretical

Qualitative/semi-structured interview

Mixed: quantitative/descriptive and inferential, and qualitative methods/interview and focus group

Qualitative methodology based on in-depth interviews

Multidisciplinary method that combines qualitative and quantitative research techniques, such as structured interviews, content analysis, and questionnaire 
Table 2. (Cont.) Main characteristics of the publications included in the qualitative synthesis.

\begin{tabular}{|c|c|c|c|}
\hline ID & Publication & Sample & Methodology \\
\hline P33 & $\begin{array}{l}\text { Ufarte, Anzera, and } \\
\text { Murcia (2020) }\end{array}$ & $\begin{array}{l}\text { Three projects: Maldito Bulo, Newtral } \\
\text { Media Audiovisual, and Pagella Politica }\end{array}$ & $\begin{array}{l}\text { Qualitative methodology/case study and } \\
\text { in-depth semi-structured interviews } \\
\text { (conducted with co-founding members of } \\
\text { Maldito Bulo and Pagella Politica) }\end{array}$ \\
\hline P34 & $\begin{array}{l}\text { Ufarte, Fieiras, and } \\
\text { Túñez (2020) }\end{array}$ & $\begin{array}{l}768 \text { subjects from } 17 \text { undergraduate } \\
\text { study programmes and } 116 \text { subjects from } \\
\text { eight master's degrees offered by } \\
\text { universities in Spain }\end{array}$ & Mixed: literature review and case study \\
\hline P35 & $\begin{array}{l}\text { Valencia-Forrester } \\
\text { (2020) }\end{array}$ & Not applicable & Theoretical \\
\hline P36 & van Laar et al. (2020) & 87 journalists & Quantitative/survey \\
\hline P37 & $\begin{array}{l}\text { Viljakainen and } \\
\text { Toivonen (2014) }\end{array}$ & 10 publishers of consumer magazines & Qualitative/in-depth interviews \\
\hline P38 & $\begin{array}{l}\text { Wagner and Boczkowski } \\
\text { (2019) }\end{array}$ & $\begin{array}{l}71 \text { participants in Chicago, Philadelphia, } \\
\text { and Miami }\end{array}$ & Qualitative/in-depth interviews \\
\hline P39 & Walker (2019) & Not applicable & Theoretical \\
\hline
\end{tabular}

Once the results have been analysed by their main characteristics, drawing on Bloom's (1956) taxonomy that delineates a hierarchy of cognitive-learning levels and Cruz's (2020) typologies of competencies of digital journalists, we have designed a classification (see Table 3) to organise the main results of the selected 39 publications. As explained above, this categorization allows us to conduct an in-depth analysis of the competencies required by future journalism professionals and the level of development of these competencies, leading to concrete actions.

Bloom's (1956) cognitive competencies refer to the competency of learning to learn. These competencies are essential for training students in new skills and abilities adapted to their future jobs and professional challenges, due to the impact of digitalisation and technological innovation. Moreover, these cognitive competencies usually imply a hybridisation between the journalist's classic qualities and emerging technologies (Calvo \& Ufarte, 2020), which flows into a hybridisation of profiles and transversality of knowledge, skills, and attitudes (Gulyas, 2017; Ufarte et al., 2018). In contrast, social competencies create a deeper discussion since these skills require journalists to interact with other users on different social platforms and gather information in order to understand how users behave and what the audiences' wishes are on the internet.

Having explored the competencies and their levels of development, the studies found in the systematic review will be categorized using the DigCompEdu framework model (Redecker, 2017; see Table 4). As already explained, this procedure will allow us to shed light on which dimensions of digital competence are being emphasized and which are being neglected. Assuming that all dimensions of digital competence are desirable and have approximately the same weight within the model, we understand that none of them should be neglected if we want to train professionals prepared for a digital world and in the continuous advancement of technologies.

As seen above, the results showed a clear imbalance in the dimensions of digital competence found in the literature. Specifically, it can be concluded that studies are putting the focus of attention on aspects based on the mastery and use of Digital Resources with $87 \%$ of studies that support this. Secondly, there was a pledge to generate the commitment of communication professionals with their job (Professional Engagement, 56\%), including aspects such as Data Management or Professional Collaboration, and a mastery of the ability of Digital Assessment (60\%), mainly related to the need to develop the ability to differentiate truthful and quality information within the digital information ecosystem. On the other side, we could see how fundamental aspects such as developing the journalists' ability to develop their digital skills $(27 \%)$, empowering the professional, gaining confidence and security about their own abilities (27\%), or encouraging the learning of an appropriate digital culture and professional health $(20 \%)$, were those with the lowest percentage of occurrence.

These results collide worryingly with those found in Bloom's categorization (Figure 6), in which we found articles that mainly focused on the Knowledge (44\%) and Comprehension (44\%) dimensions, which are the lowest levels of Bloom's pyramid. The rest of the levels, such as Analysis (15\%), Synthesis (18\%) or Application (28\%), have very low values, considering the number of articles analysed. As it happened with the evaluation dimension in the findings based on DigComEdu, we observe, 
Table 3. Digital competencies for new journalistic work in media organisations.

\begin{tabular}{|c|c|c|c|}
\hline Competencies & Definition & Task & Publications \\
\hline Knowledge & $\begin{array}{l}\text { Remember and memorise facts, } \\
\text { principles, and concepts; } \\
\text { evoking or recognising facts, } \\
\text { events, or theories that have } \\
\text { been learned }\end{array}$ & $\begin{array}{l}\text { Memorise facts, principles, and } \\
\text { conceptions }\end{array}$ & $\begin{array}{l}\text { P1, P3, P4, P11, P13, P16, P14, } \\
\text { P17, P18, P19, P33, P34, P32, } \\
\text { P37, P2, P35, P38. }\end{array}$ \\
\hline Comprehension & $\begin{array}{l}\text { Organise events in such a way } \\
\text { that makes sense; translating } \\
\text { materials from one form to } \\
\text { another, interpreting materials, } \\
\text { or predicting future trends }\end{array}$ & $\begin{array}{l}\text { Understand the information } \\
\text { received }\end{array}$ & $\begin{array}{l}\text { P7, P8, P13, P16, P17, P18, P19, } \\
\text { P25, P28, P30, P31, P32, P36, } \\
\text { P37, P35, P26, P38 }\end{array}$ \\
\hline Application & $\begin{array}{l}\text { Apply the concepts or } \\
\text { principles learned to solve new } \\
\text { problems or handle new } \\
\text { situations and to use learned } \\
\text { materials in a new and } \\
\text { concrete situation }\end{array}$ & $\begin{array}{l}\text { Remember the information } \\
\text { and apply it correctly }\end{array}$ & $\begin{array}{l}P 1, P 10, P 13, P 17, P 25, P 28, \\
P 31, P 36, P 2, P 35, P 38\end{array}$ \\
\hline Analysis & $\begin{array}{l}\text { Ability to examine a concept } \\
\text { and disaggregate it into its } \\
\text { component elements, as well } \\
\text { as to analyse the relations } \\
\text { between and among parts }\end{array}$ & $\begin{array}{l}\text { Ungroup the information into } \\
\text { parts and determine how it is } \\
\text { organised }\end{array}$ & $\mathrm{P} 12, \mathrm{P} 17, \mathrm{P} 19, \mathrm{P} 25, \mathrm{P} 27, \mathrm{P} 28$ \\
\hline Synthesis & $\begin{array}{l}\text { Synthesise or propose new } \\
\text { ways to value information; } \\
\text { ability to resolve contradictions } \\
\text { and put parts together to form } \\
\text { a new whole }\end{array}$ & $\begin{array}{l}\text { Propose new ways to } \\
\text { understand the information }\end{array}$ & $\begin{array}{l}\text { P17, P18, P19, P25, P27, P28, } \\
\text { P36, P2, P35, P26 }\end{array}$ \\
\hline Evaluation & $\begin{array}{l}\text { Ability to make critical } \\
\text { judgements for a specific } \\
\text { situation or a concrete purpose }\end{array}$ & $\begin{array}{l}\text { Value the information from } \\
\text { quantitative and qualitative } \\
\text { perspectives }\end{array}$ & $\begin{array}{l}\text { P12, P13, P17, P18, P19, P20, } \\
\text { P21, P31, P32, P33, P36, P35, } \\
\text { P26, P9, P5 }\end{array}$ \\
\hline $\begin{array}{l}\text { Individual } \\
\text { competencies }\end{array}$ & $\begin{array}{l}\text { Ability to reflect on one's } \\
\text { actions in digital environments; } \\
\text { ability to direct and focus } \\
\text { personal attention }\end{array}$ & $\begin{array}{l}\text { Act correctly in a wide variety } \\
\text { of situations }\end{array}$ & $\begin{array}{l}\text { P1, P6, P8, P12, P13, P14, P17, } \\
\text { P19, P22, P29, P30, P31, P33, } \\
\text { P32, P37, P24, P2, P35, P26, } \\
\text { P38, P39, P5 }\end{array}$ \\
\hline $\begin{array}{l}\text { Social } \\
\text { competencies }\end{array}$ & $\begin{array}{l}\text { Ability to act in a socially } \\
\text { responsible manner as a } \\
\text { community member; ability to } \\
\text { interact with social, } \\
\text { technological, and educational } \\
\text { networks; ability to work with } \\
\text { others }\end{array}$ & $\begin{array}{l}\text { Adopt a new way of interacting } \\
\text { and socialising, not only } \\
\text { between and among subjects, } \\
\text { but between the audience and } \\
\text { the content as well }\end{array}$ & $\begin{array}{l}\text { P7, P13, P14, P15, P17, P20, } \\
\text { P21, P29, P30, P31, P33, P32, } \\
\text { P24, P2, P35, P26, P9, P23 }\end{array}$ \\
\hline
\end{tabular}

Note: Publications may contribute to more than one competency. Source: Adapted from Bloom (1956) and Cruz (2020).

regarding Bloom's taxonomy, several articles that point to the need to develop this competence (38\%). The rise of fake news is undoubtedly of concern to all agents involved in the communication field. Finally, the aspects related to Individual (50\%) and Social (49\%) competencies have high values, which are in line with the Professional Engagement dimension of the DigCompEdu model. Thus, there is a tendency in the media outlets that pushes journalists to acquire competencies related to teamwork, and to empathise with the audience and their job through self-directed learning, lifelong learning, etc.

Based on these results, we affirm that there is still a long way to go to establish training needs that holistically satisfy all the dimensions present in digital competence; 
in particular, those that can promote higher levels of professional satisfaction such as empowerment, learning healthy work habits and other aspects that are not being incorporated or demanded by media outlets. Becoming aware of these aspects can be the first step to generate transformation and value in future curricula with a vision that is able to collect both the needs of the media outlets and the needs of the professional.

Table 4. Studies and dimensions of digital competence based on digital competence in education.

\begin{tabular}{llll}
\hline Dimensions & Definition & Studies & Total N = 30 (\%) \\
\hline 1. Professional & Refers to digital skills and abilities to improve & P1, P3, P8, P9, P12, P14, & 17 (56\%) \\
Engagement & organizational communication between different & P18, P20, P21, P22, P27, & \\
& $\begin{array}{l}\text { agents; establish networks for professional } \\
\text { collaboration, make use of reflective practice and }\end{array}$ & P29, P30, P33, P36, & \\
& serve for continuous professional training & &
\end{tabular}

2. Digital
Resources

3. Digital

Pedagogy

4. Digital

Assessment

5. Empowering Learners

6. Facilitating Learners' Digital

Competences
Refers to the capacity to select appropriate resources; create and/or modify existing digital resources to respond to objectives; as well as knowing how to manage, protect, share, and understand the use of open resources

Refers to the use of digital resources and tools for lifelong learning and for professional innovation; it consists of developing skills that guide professional, collaborative, and self-directed learning

Use of digital tools to improve the evaluation process; is linked to evaluation strategies through $\mathrm{ICT}$, understood in the context of using digital tools to evaluate information quality and veracity

Related to ensuring that professionals have the ability to access and handle all kinds of digital resources to solve tasks in their workplace; is about exploiting the potential of ICT to reduce possible gaps; personalize differentiated learning itineraries and achieve the active participation of professionals, fostering an active commitment

Linked to practices that promote the development of digital competences; is specified in posing challenges based on real problems that involve the use of technologies
P4, P5, P6, P7, P8, P10, P11, 26 (87\%)

$\mathrm{P} 13, \mathrm{P} 16, \mathrm{P} 15, \mathrm{P} 17, \mathrm{P} 18$,

$P 19, P 21, P 22, P 24, P 25$,

P26, P28, P30, P31, P33,

P34, P32, P38, P39

P1, P2, P16, P20, P24, P26

$6(20 \%)$

P1, P3, P5, P6, P11, P12,

$P 17, P 18, P 19, P 20, P 25$,

P26, P28, P33, P34, P32,

P38, P39

$\mathrm{P} 1, \mathrm{P} 14, \mathrm{P} 23, \mathrm{P} 24, \mathrm{P} 29, \mathrm{P} 32, \quad 8(27 \%)$

P37, P38

P1, P3, P13, P23, P24, P26,

P29, P36

Note: Publications may contribute to more than one dimension.

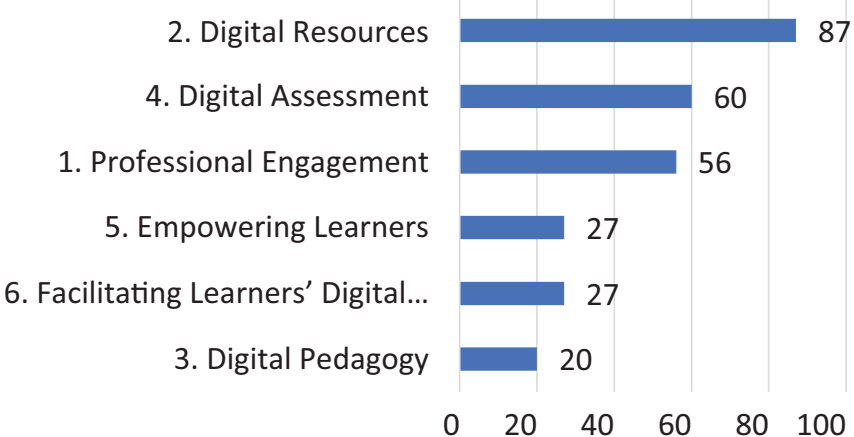

Individual competencies

Social competencies

Comprehension

Knowledge

Evaluation

Application

Synthesis

Analysis

0

$0 \quad 20$

40

Figure 6. Comparison of the results based on the digital competence in education model and Bloom's taxonomy. 


\section{Conclusions}

This study provides an important insight into the key aspects of digital competence and skills required by journalism professionals that are currently in demand. In addition, the systematic review of the literature that we have carried out in this work has determined which aspects or dimensions of digital competence are being privileged in the last 10 years. The application of the two models recognized by the scientific community of digital competence, such as Bloom's taxonomy (1956) and the DigCompEdu model (Redecker, 2017), has served as a theoretical framework in two ways: to determine the level of digital competence development (Bloom), and identify the dimensions on which greater emphasis is being placed. The value and originality of this work lie in the comparison of both models to extract a holistic view of the new digital competencies demanded by the media outlets, by measuring, at the same time, the areas in which digital competency is specified and its level of development.

Focusing on the characteristics of the works and following the taxonomy of authors such as Pozo et al. (2012), we conclude that the studies in the systematic review aim attention at collecting the opinion of communication professionals (managers, publishers, producers, etc.). Although this could be considered opportune and necessary, the great difference in the results obtained shows a clear tendency to favour the needs of the industry, which can lead to a neglect of the demands and proposals of both students and teachers, ultimately affecting future journalists. Some authors share this concern and demand the development of studies with a perspective focused on other actors in the sector (Tsymbal et al., 2020; van Laar et al., 2020).

These results are further supported by the comparative analysis of digital competence models. The analysis results have shown that there is a high proliferation of studies focused on competencies development related to improving organizational communication and marketing (e.g., Schaich, 2012), establishing networks for professional collaboration (e.g., Josephi, 2019), or making use of reflective practise (e.g., Aceituno et al., 2014; Jiang \& Rafeeq, 2019; Macmillan, 2014). On the contrary, neglecting competencies development related to personalizing differentiated learning itineraries and achieving the active participation of professionals, fostering an active and creative commitment (e.g., Reilly, 2018; Robinson et al., 2021; Stoker, 2015). As well as posing challenges that involve the use of technologies to provide answers and promoting the development of digital skills (e.g., Appelgren \& Lindén, 2020; Lazo et al., 2020; Saks et al., 2019) linked to aspects of individual and emotional nature: Empowering Learners and Facilitating Learners' Digital Competences dimensions (Green et al., 2017; Peters et al., 2018).

The results of this analysis also show that another of the key aspects found after the literature review has been to discover that from the point of view of the development of digital competence (according to Bloom, 1956), the studies focus on the most basic levels of digital competence: specifically, the Knowledge and Comprehenssion levels. These results converge, worryingly, with those of the analysis following the DigCompEdu framework (Redecker, 2017), in which studies focus on the Digital Resources dimension. This may highlight a tendency on the part of the media outlets towards the demand for worker profiles with very specific roles in the mastery and use of digital resources, but without paying special attention to cognitively higher aspects of digital competence (such as the level of Analysis, Synthesis, and Evaluation). These findings coincide with the concern of authors (Alexander \& Giarraffa, 2021) who point out, as a general problem, the current trend of university curricula towards a more professionalizing than academic orientation, reducing the distance between the university world and professional training. If this were the case, it might inevitably lead to a proliferation of communication professionals who are very expert in certain tasks, but with a lack of global vision of the environment and with visible skills deficiencies. However, as some authors (Jagannathan et al., 2019; Rainie \& Anderson, 2017) have highlighted, this may be a consequence of an increasingly sectorized world of work. It is important to note that current educational models of digital competence raise the alarm that it is as necessary to develop skills related to the use of resources as it is to develop other dimensions of digital competence (linked, as mentioned above, to personal development and personal empowerment, improved well-being, time management, etc.; Schleicher, et al., 2019).

In summary, this article contributes to the field of journalism research by providing a vision of digital competence linked to the current moment of work in the communication sector. Our results bring to light a lack of studies linked to some key aspects of digital competence, especially those related to personal growth, emotional state (Redecker, 2017), and the development of a deep level (Bloom, 1956) of digital competence acquisition. These results may serve to reflect on the need to look at the curricula of journalism and communication degrees and reflect about whether we want to train professionals following the model demanded by the media outlets, or whether we would like to train professionals with a deep level of digital competences. Nevertheless, despite that the DigEduComp framework is a global model, standardized throughout Europe and recognized in many Western countries, the national context could be a key factor that influences the interpretation of the results.

\section{Conflict of Interests}

The authors declare no conflict of interests. 


\section{References}

Abbott, J. Y. (2017). Tensions in the scholarship on participatory journalism and citizen journalism. Annals of the International Communication Association, 41(3/4), 278-297.

Aceituno, P., Bousoño, C., Escudero, J., \& Herrera, F. (2014). Formación en emprendimiento para periodistas [Entrepreneurship training for journalists]. El Profesional de la Información, 23(4), 409-414. https:// doi.org/10.3145/epi.2014.jul.09

Alexander, J., \& Giarraffa, P. (2021). Use of experiential learning in higher education today. In P. Northrup, K. Rasmuss, \& R. Colson (Eds.), Career Ready Education Through Experiential Learning (pp. 59-67). IGI Global.

Anderson, S., \& Bourke, B. (2020). Teaching collegiate journalists how to cover traumatic events using moral development theory. Journalism and Mass Communication Educator, 75(2), 233-246. https:// doi.org/10.1177/1077695819891020

Appelgren, E., \& Lindén, C. G. (2020). Data journalism as a service: Digital native data journalism expertise and product development. Media and Communication, 8(2), 62-72. https://doi.org/10.17645/mac. v8i2.2757

Berganza, R., Lavín, E., \& Piñeiro-Naval, V. (2017). Spanish journalists' perception about their professional roles. Comunicar, 25(51), 83-92.

Bloom, B. S. (1956). Taxonomy of educational objectives. Vol. 1: Cognitive domain. David McKay.

Bruns, A. (2016). Big data analysis. In T. Witschge, C. W. Anderson, D. Domingo, \& A. Hermida (Eds.), The SAGE handbook of digital journalism (pp. 509-527). SAGE.

Burum, I., \& Quinn, S. (2016). The mobile journalism handbook. Focal Press.

Cairo, A. (2015). Graphics lies, misleading visuals reflections on the challenges and pitfalls of evidencedriven visual communication. In D. Bihanic (Ed.), New challenges for data design (pp. 103-116). Springer.

Calvo, L., \& Ufarte, J. (2020). Perception of teachers, students, innovation managers and journalists about the use of artificial intelligence in journalism. El Profesional de la Información, 29(1). https://doi.org/ 10.3145/epi.2020.ene.09

Carlson, M. (2017). Journalistic authority: Legitimating news in the digital era. Columbia University Press.

Chadwick, A. (2011). The political information cycle in a hybrid news system: The British prime minister and the "bullygate" affair. International Journal of Press/Politics, 16(1), 3-29. https://doi.org/10.1177/ 19401612103847307

Chen, X. (2018). Calling out fake news on social media: A comparison of literature in librarianship and journalism. Internet Reference Services Quarterly, 23(1/2), 1-13. https://doi.org/10.1080/10875301. 2018.1518284
Chung, D. S. (2008). Interactive features of online newspapers: Identifying patterns and predicting use of engaged readers. Journal of Computer-Mediated Communication, 13(3), 658-679. https://doi.org/ 10.1111/j.1083-6101.2008.00414.x

Colás-Bravo, P., Conde-Jiménez, J., \& Reyes-de-Cózar, S. (2021). Sustainability and digital teaching competence in higher education. Sustainability, 13(22), 12354. https://doi.org/10.3390/su132212354

Counsell, C. (1997). Formulating questions and locating primary studies for inclusion in systematic reviews. Annals of Internal Medicine, 127(5), 380-387. https://doi.org/10.7326/0003-4819-1275-199709010-00008

Cruz, J. (2020). Competencias y metacompetencias de los periodistas digitales [Competencies and metacompetencies of digital journalists]. Revista de Comunicación y Cultura, 2020(3), 53-66. https://doi.org/ 10.32719/26312514.2020.3.5

Cruz-Álvarez, J., \& Suarez-Villegas, J. C. (2017). Pautas deontológicas para el periodismo digital [Ethical guidelines for digital journalism]. El Profesional de la Información, 26(2), 249-254. https://doi.org/ 10.3145/epi.2017.mar.11

Currie, T. (2012). Social media editors in the newsroom: A survey of roles and functions [Paper presentation]. AEJMC 2012 Chicago Conference, Chicago, IL, USA.

Diakopoulos, N. (2015). Algorithmic accountability: Journalistic investigation of computational power structures. Digital Journalism, 3(3), 398-415. https://doi. org/10.1080/21670811.2014.976411

Engelke, K. M. (2019). Online participatory journalism: A systematic literature review. Media and Communication, 7(4), 31-44. https://doi.org/10.17645/mac. v7i4. 2250

Flores, J. (2018). Algorithms, applications and big data, new paradigms in the process of communication and teaching-learning of data journalism. Revista de Comunicación, 17(2), 268-291. https://doi.org/ 10.26441/RC17.2-2018-P14

García-Orosa, B., López-García, X., \& Vázquez-Herrero, J. (2020). Journalism in digital native media: Beyond technological determinism. Media and Communication, 8(2), 5-15. https://doi.org/10.17645/mac.v8i2. 2702

Goggin, G. (2020). Digital journalism after mobility. Digital Journalism, 8(1), 170-173. https://doi.org/ 10.1080/21670811.2019.1711434

GPT-3. (2020, September 8). A robot wrote this entire article. Are you scared yet, human? The Guardian. https://bit.ly/3edFBnk

Grant, M. J., \& Booth, A. (2009). A typology of reviews: An analysis of 14 review types and associated methodologies. Health Information and Libraries Journal, 26(2), 91-108. https://doi.org/10.1111/j.1471-1842. 2009.00848.x

Graves, L. (2016). Deciding what's true: The rise of polit- 
ical fact-checking in American journalism. Columbia University Press.

Green, P. I., Finkel, E. J., Fitzsimons, G. M., \& Gino, F. (2017). The energizing nature of work engagement: Toward a new need-based theory of work motivation. Research in Organizational Behavior, 37, 1-18.

Gulyas, A. (2017). Hybridity and social media adoption by journalists: An international comparison. Digital Journalism, 5(7), 884-902. https://doi.org/10.1080/ 21670811.2016.1232170

Hassid, J. (2012). Safety valve or pressure cooker? Blogs in Chinese political life. Journal of Communication, 62(2), 212-230. https://doi.org/10.1111/ j.1460-2466.2012.01634.x

Heravi, B., Cassidy, K., Davis, E., \& Harrower, N. (2021). Preserving data journalism: A systematic literature review. Journalism Practice. Advance online publication. https://doi.org/10.1080/17512786.2021. 1903972

Jagannathan, S., Ra, S., \& Maclean, R. (2019). Dominant recent trends impacting on jobs and labor markets: An overview. International Journal of Training Research, 17(1), 1-11.

Jensen, J. L., Mortensen, M., \& Ørmen, J. (2016). News across media: Production, distribution and consumption. Routledge.

Jiang, S., \& Rafeeq, A. (2019). Connecting the classroom with the newsroom in the digital age: An investigation of journalism education in the UAE, UK and USA. Asia Pacific Media Educator, 29(1), 3-22.

Josephi, B. (2019). Which bedrock in a sea of change? Journalism, 20(5), 679-687. https://doi.org/ $10.1177 / 1464884918760673$

Karaduman, M. (2015). A critical view on communication education and training: An evaluation in the context of communication high school. Procedia-Social and Behavioral Sciences, 174, 3033-3038.

Kõuts-Klemm, R. (2019). Data literacy among journalists: A skills-assessment based approach. Central European Journal of Communication, 12(3), 299-315. https://doi.org/10.19195/1899-5101.12.3(24).2

Labio-Bernal, A., García-Orta, M. J., Romero-Domínguez, L. R., \& García-Prieto, V. (2020). Digital information skills, media literacy and journalism in Spain. A case study on the "Press in Schools" project. ICONO 14, Revista de Comunicación y Tecnologías Emergentes, 18(2), 58-83.

Lazo, C., Rodríguez, J., \& Peñalva, S. (2020). Digital journalism competencies. Systematic review of the scientific literature on new professional profiles of the journalist. Revista Latina de Comunicación Social, 2020(75), 53-68. https://doi.org/ 10.4185/RLCS-2020-1416

Lewis, S. C., \& Westlund, O. (2016). Mapping the humanmachine divide in journalism. In T. Witschge, C. W. Anderson, D. Domingo, \& A. Hermida (Eds.), The SAGE handbook of digital journalism (pp. 341-353). SAGE.

López, X., Rodríguez, A., \& Toural, C. (2019). Social and technological dimensions: The renewed strength of journalist profiles for an intelligent automation phase. Estudios Sobre el Mensaje Periodístico, 25(3), 1499-1508. https://doi.org/10.5209/esmp.67000

López-Vidales, N., \& González-Aldea, P. (2014). Audioblogs and tvblogs, tools for collaborative learning in journalism. Comunicar, 21(42), 45-53. https://doi.org/10.3916/C42-2014-04

López-Martín, Á., \& Córdoba-Cabús, A. (2020). Características y competencias de la enseñanza del periodismo digital en el grado de periodismo en las universidades públicas españolas [Characteristics and competences of the teaching of digital journalism in the degree of Journalism in Spanish public universities]. Dixit, 2020(33), 61-73.

Luengo, M., \& García-Marín, D. (2020). The performance of truth: Politicians, fact-checking journalism, and the struggle to tackle Covid-19 misinformation. American Journal of Cultural Sociology, 8, 405-427. https://doi.org/10.1057/s41290-020-00115-w

Lugo-Ortiz, L. (2016). The academia, the media, and the ideal professional: A generalist-multimedia journalist. Communication \& Society, 29(4), 271-286. https:// doi.org/10.15581/003.29.4.271-286

Macmillan, M. E. (2014). Fostering the integration of information literacy and journalism practice: A long-term study of journalism students. Journal of Information Literacy, 8(2), 3-22. https://doi.org/ 10.11645/8.2.1941

Manfredi, J., Ufarte, M., \& Herranz, J. (2019). Journalistic innovation and digital society: An adaptation of journalism studies. Revista Latina de Comunicación Social, 74, 1633-1654. https://doi.org/ 10.4185/RLCS-2019-1402

mediagrr19. (2009, May 7). David Simon testifying about the future of newspapers. [Video]. https://youtu.be/ Llnbzq7b4Ww

Moher, D., Liberati, A., Tetzlaff, J., Altman, D. G., \& The Prisma Group. (2009). Preferred reporting items for systematic reviews and metaanalyses: The PRISMA statement. PLoS Medicine, 6(7). Article e1000097. https://doi.org/10.1371/journal.pmed.1000097

Myers, S. (2011, September 2). Social media editor role expands to include fighting misinformation during breaking news. Poynter. https://bit.ly/3stMztu

Oliveira, A. P. B., \& Angeluci, A. C. B. (2019). Competences and skills in data journalism: Perceptions on the profile of Brazilian professionals. Brazilian Journalism Research, 15(2), 381.

Paine, E. (2015). The next step: Social media and the evolution of journalism [Doctoral thesis, Salem State University]. Digital Commons at Salem State University. https://bit.ly/3tBxszA

Pellegrini, S., \& Grassau, D. (2018). Work key: A theoretical-technological path to organize the hidden components of communication. Palabra Clave, 21(4), 1050-1074. https://doi.org/10.5294/pacla.2018.21. 4.5 
Peters, D., Calvo, R. A., \& Ryan, R. M. (2018). Designing for motivation, engagement and wellbeing in digital experience. Frontiers in Psychology, 9, 797.

Petticrew, M. (2001). Systematic reviews from astronomy to zoology: Myths and misconceptions. British Medical Journal, 322(7278), 98-101. https://doi.org/ 10.1136/bmj.322.7278.98

Petticrew, M., \& Roberts, H. (2006). Systematic reviews in the social sciences: A practical guide. Blackwell.

Pickard, V., \& Yang, G. (2017). Media activism in the digital age. Routledge.

Pozo, M. T., Suárez Ortega, M., \& García-Cano Torrico, M. (2012). Logros educativos y diversidad en la escuela: Hacia una definición desde el consenso [Educational achievements and diversity in school: Towards a definition from consensus]. Revista de Educación, 358, 59-84. https://doi.org/10--4438/1988592X-RE-2012-358-183

Rainie, L., \& Anderson, J. (2017). The Future of Jobs and Jobs Training. Pew Research Center.

Recio, J., \& Santos, J. (2014). Integrative model for training communications professional in virtual environments: Creating entrepreneurs. Investigación Bibliotecológica, 28(64), 75-100. https://doi.org/ 10.1016/s0187-358x(14)70910-4

Redecker, C. (2017). European framework for the digital competence of educators: DigCompEdu. Publications Office of the European Union. https://doi.org/ $10.2760 / 178382$

Reilly, J. E. (2018). Reporting without knowledge: The absence of human rights in US journalism education. Human Rights Review, 19(2), 249-271. https://doi. org/10.1007/s12142-018-0493-7

Renó, D., \& Flores, J. (2012). Periodismo transmedia [Transmedia journalism]. Fragua.

Renó, D., \& Renó, L. (2015). The newsroom, big data and social media as information sources. Estudios Sobre El Mensaje Periodístico, 21, 131-142. https:// doi.org/http://dx.doi.org/10.5209/rev_ESMP.2015. v21.51135

Robinson, S., Jensen, K., \& Dávalos, C. (2021). “Listening literacies" as keys to rebuilding trust in journalism: $\mathrm{A}$ typology for a changing news audience. Journalism Studies, 22(9), 1219-1237. https://doi.org/10.1080/ 1461670X.2021.1937677

Rogers, T. (2016). What is citizen journalism. Thoughtco.com. https://bit.ly/2QjGwKP

Saavedra, M., Herrera, M., \& Castillo, E. (2020). Training in data journalism in Spain: An overview of the higher education academic offering. Anàlisi, 62, 93-109. https://doi.org/10.5565/rev/analisi.3283

Saks, J., Cruikshank, S. A., \& Yanity, M. (2019). U.S. college student media and twitter: Are student media following best practices? Journalism and Mass Communication Educator, 74(3), 290-305. https://doi. org/10.1177/1077695818797202

Salaverría, R. (2019). Digital journalism: 25 years of research. Review article. El Profesional de la Informa- ción, 28(1). https://doi.org/10.3145/epi.2019.ene. 01

Salaverría, R., \& De-Lima-Santos, M. F. (2020). Towards ubiquitous journalism: Impacts of IoT on news. In J. Vázquez-Herrero, S. Direito-Rebollal, A. SilvaRodríguez, \& X. López-García (Eds.), Journalistic metamorphosis: Media transformation in the digital age (pp. 1-16). Springer.

Sánchez-García, P. (2016). The effects of the first phase of the EHEA in journalism education in Spain: More specialized and practical training. Comunication \& Society, 29(1), 125-142. https://doi.org/10.15581/003. 29.1.125-142

Schaich, M. J. V. (2012). The rise of entrepreneurial journalism education and a sample case study for teaching. Vivat Academia, 14(117), 1545.

Schleicher, A., Achiron, M., Burns, T., Davis, C., Tessier, R., \& Chambers, N. (2019). Envisioning the future of education and jobs: Trends, data and drawings. OECD.

Sewchurran, A., \& Hofmeyr, B. (2020). A critical reflection on digital disruption in journalism and journalism education. Acta Academica, 52(2), 181-203. https:// doi.org/10.18820/24150479/aa52i2/10

Shirky, C. (2008). Here comes everybody: The power of organizing without organizations. Penguin Press.

Siddaway, A. P., Wood, A. M., \& Hedges, L. V. (2019). How to do a systematic review: A best practice guide for conducting and reporting narrative reviews, metaanalyses, and meta-syntheses. Annual Review of Psychology, 70(1), 747-770. https://doi.org/10.1146/ annurev-psych-010418-102803

Steensen, S., \& Westlund, O. (2021). What is digital: Journalism studies? Routledge.

Stoker, R. (2015). An investigation into blogging as an opportunity for work-integrated learning for journalism students. Higher Education, Skills and WorkBased Learning, 5(2), 168-180. https://doi.org/ 10.1108/HESWBL-01-2014-0002

Tsymbal, N., Savchuk, N., Avramenko, V., Sichkar, S., \& Denysiuk, I. (2020). Mass media internships in vocational training of students majoring in journalism. International Journal of Learning, Teaching and Educational Research, 19(6), 238-250. https://doi.org/ 10.26803/IJLTER.19.6.14

Túñez, J., Fieiras, C., \& Vaz, M. (2021). Impact of artificial intelligence on journalism: Transformations in the company, products, contents, and professional profile. Communication and Society, 34(1), 177-193. https://doi.org/10.15581/003.34.1.177-193

Ufarte, M., Anzera, G., \& Murcia, F. (2020). Plataformas independientes de fact-checking en España e Italia. Características, organización y método [Independent fact-checking platforms in Spain and Italy. Features, organisation and method]. Revista Mediterránea de Comunicación, 11(2), 23-39. https://doi. org/10.14198/MEDCOM2020.11.2.3

Ufarte, M., Fieiras, C., \& Túñez, M. (2020). The teachinglearning of automated journalism in public institu- 
tions: Studies, feasibility proposals and future impact of artificial intelligence. Anàlisi, 62, 131-146. https:// doi.org/10.5565/rev/analisi.3289

Ufarte, M., Peralta, L., \& Murcia, F. (2018). Fact checking: Un nuevo desafío del periodismo [Fact checking: A new challenge in journalism]. El Profesional de la Información, 27(4), 733-741. https://doi.org/ 10.3145/epi.2018.jul.02

Urrutia, G., \& Bonfill, X. (2013). La declaración PRISMA: Un paso adelante en la mejora de las publicaciones de la Revista Española de Salud Pública [The PRISMA declaration: A step forward in improving the publications of the Revista Española de Salud Pública]. Revista Española de Salud Pública, 87(2), 99-102. https://doi.org/10.4321/S1135-57272013 000200001

Valencia-Forrester, F. (2020). Models of work-integrated learning in journalism education. Journalism Studies, 21(5), 697-712. https://doi.org/10.1080/1461670X. 2020.1719875

van Laar, E., Van Deursen, A. J., Van Dijk, J. A., \& De Haan, J. (2020). Measuring the levels of 21st-century digital skills among professionals working within the creative industries: A performance-based approach.
Poetics, 81, 101434.

Viljakainen, A., \& Toivonen, M. (2014). The futures of magazine publishing: Servitization and co-creation of customer value. Futures, 64, 19-28.

Wagner, M. C., \& Boczkowski, P. J. (2019). The reception of fake news: The interpretations and practices that shape the consumption of perceived misinformation. Digital Journalism, 7(7), 870-885. https://doi.org/ 10.1080/21670811.2019.1653208

Walker, A. S. (2019). Preparing students for the fight against false information with visual verification and open source reporting. Journalism and Mass Communication Educator, 74(2), 227-239. https://doi.org/ 10.1177/1077695819831098

Williams, J. R. (2019). The use of online social networking sites to nurture and cultivate bonding social capital: A systematic review of the literature from 1997 to 2018. New Media \& Society, 21(11/12), 1-20. https:// doi.org/10.1177/1461444819858749

Zavoina, S., \& Reichert, T. (2000). Media convergence/management change: The evolving workflow for visual journalists. The Journal of Media Economics, 13(2), 143-151. https://doi.org/10.1207/ S15327736ME1302_6

\section{About the Authors}
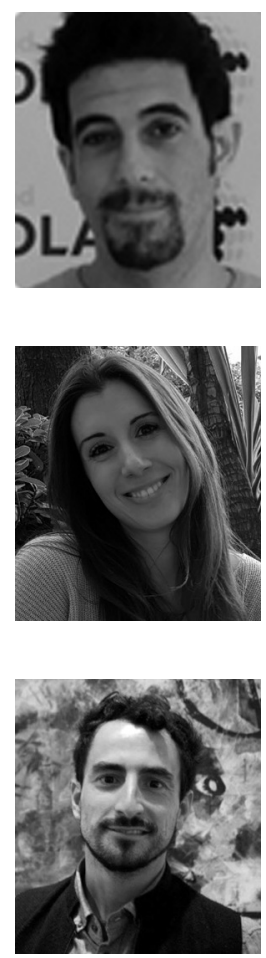

Salvador Reyes-de-Cózar holds a PhD in education sciences from the University of Seville (Spain) and has an MA in management, evaluation, and quality of training institutions. He has participated in several research projects at the European level: Disiciplins, STAY IN, DEPIT, and Teaching to Be (T2B), acting as principal investigator within the partner Universidad Loyola Andalucía. Currently, he is a fulltime senior lecturer in the Department of Communication and Education of the Universidad Loyola Andalucía and has published several book chapters and articles in publishers indexed in the SPI, JCR, and SCOPUS index.

Marta Pérez-Escolar holds a PhD in communication science from the Catholic University of Saint Anthony (Spain). In 2018, she received the Civic Participation, Transparency and Good Governance PhD Extraordinary Award-granted by the Region of Murcia (Spain)-for her doctoral thesis. She is currently an assistant professor in the Department of Communication at Universidad Loyola Andalucía (Sevilla, Spain), where she teaches subjects such as public opinion and theory of communication. Her research focuses on civic participation, political communication, public opinion, and information disorders.

Pablo Navazo-Ostúa (PhD) was doctor cum laude in information sciences from Complutense University of Madrid (Spain). Specialist in audiovisual communication, graphic design, and contemporary art, he is professor and culture service coordinator at Universidad Loyola Andalucía. He has developed initiatives in the cultural sector for relevant institutions such as the Cervantes Institute and the Ministry of Culture under the CULTUREX project on cultural management training in various European countries. He teaches subjects such as innovation, media and digital content in undergraduate and MA degree courses at Universidad Loyola Andalucía in Seville and digital marketing at Camilo José Cela University in Madrid. 